\title{
Qualitative and Quantitative Evaluation of Phytochemical Constituents of Selected Horticultural and Medicinal Plants in Nigeria
}

\author{
Olusimbo Kenneth-Obosi ${ }^{1}$, Olaniyi Jacob Babayemi ${ }^{2}$ \\ ${ }^{1}$ Farming System and Extension Department, National Horticultural Research Institute, Ibadan, Nigeria \\ ${ }^{2}$ Department of Animal Science, University of Ibadan, Ibadan, Nigeria
}

Email address:

oyewonu@yahoo.com (O. Kenneth-Obosi), ojyemi@yahoo.co.uk (O. J. Babayemi)

\section{To cite this article:}

Olusimbo Kenneth-Obosi, Olaniyi Jacob Babayemi. Qualitative and Quantitative Evaluation of Phytochemical Constituents of Selected Horticultural and Medicinal Plants in Nigeria. International Journal of Homeopathy \& Natural Medicines. Vol. 3, No. 1, 2017, pp. 1-8. doi: 10.11648/j.ijhnm.20170301.11

Received: April 7, 2017; Accepted: May 8, 2017; Published: May 22, 2017

\begin{abstract}
Plants contain several compounds among which are phytochemicals with both beneficial (medicinal, nutritional, antibiotic and environmental) and deleterious (bitter taste, poisonous, chelate) effects on organisms consuming them. Eighteen (18) tropical plants comprising 8 herbaceous plants, 4 trees and 5 shrubs and ornamentals were assayed for their antinutritional factors using qualitative and quantitative techniques. Saponin, tannin, steroid, triterpeniod, cardiac glycoside and phlobatanins were present in all tropical plants examined. Alkaloids used in preparing poison was absent in all samples that were assayed, there were varying quantities of antinutritional factors in all. Saponin content in the plants ranged from (6.22-19.53 g/100 gDM) Adanzonia digitata and Vernonia amygdalina respectively this can be exploited for its nutritional and medicinal benefits for human, animal and environment. Enhancement of protein in form of by-pass protein can be achieved by exploiting tannin which ranged from Morinda lucida $(0.53 \mathrm{~g} / 100 \mathrm{gDM})$ to Talinum triangulae ( $2.80 \mathrm{~g} / 100 \mathrm{gDM})$, flavonoids ranged from Newbouldia laevis $(0.89 \mathrm{~g} / 100 \mathrm{gDM})$ to Physalis angulata $(10.52 \mathrm{~g} / 100 \mathrm{gDM})$. Moreover, Phenol is important for its antiseptic action ranged from $(0.60 \mathrm{~g} / 100 \mathrm{gDM})$ in Corchorus olitorium and Morinda lucida to in Talinum triangulae (3.18 g/100 gDM) $(\mathrm{p}<0.05)$. All these phytochemicals in tropical plants can be harnessed for their advantages.
\end{abstract}

Keywords: Tropical Plants, Antinutritional Factors, Beneficial, Medicinal

\section{Introduction}

Plants are the primary producers that other organisms depend upon either directly or indirectly for living. Many of the indigenous medicinal plants are used as spices and food plants [1] which are either eaten fresh directly or processed; moreover, pregnant and nursing mothers add such plants to their food because of their medicinal benefits [2]; [3]. Plants through their phytochemical contents exhibit natural defense against predators by making themselves unpalatable as well as through their bactericidal or biological activity [4]; [5]. Although potentially beneficial to human health in small doses, many such compounds are toxic when consumed in high quantity [6]. Plant-based phenols, flavonoids, alkaloids and saponins are usually, acrid, or astringent [5]. In ruminant nutrition, phytochemicals play vital role on the rumen microbes [7]. [8] Established the depressive effect of a saponin rich tropical fruit on methanogenesis in faunated and defaunated rumen fluid. Phytochemical is one of the factors that determine the amount of gas to be produced during fermentation of feed in ruminant in addition to nature of fibre and level of fibre in the feed [9]. Against this background, the present study was undertaken to determine the qualitative and quantitative constituents of phytochemicals in some tropical plants.

\section{Materials and Methods}

\subsection{Collection of Forages}

Leaves from 18 tropical plants were selected based literature report of their utilization as food, feed additives, 
and herbs. Also, some were selected based on some reported properties such as bitter taste, foam formation, anthelmintic, antibiotic etc. Selected plants include:

Herbaceous plants: Celosia argentous, Amaranthus spinosus, Amaranthus hybridus, Corchorus olitorium, Talinum triangulae, Tridax procumbens, Physalis angulata, Spigelia antheimia.

Trees: Albizia saman, Newbouldia laevis, Adanzonia digitata, Glyricidia sepium.

Shrubs and ornamentals: Ocimum gratissiumum, Vernonia amygdalina, Euphorbia unispina, Morinda lucida, Aleo vera, Helianthus tuberosus.

Leaves with petioles were collected from the Teaching and Research Farm, University of Ibadan, Ibadan, Nigeria. The area is located at $7^{\circ} 27^{\prime} \mathrm{N}$ and $3^{\circ} 45^{\prime} \mathrm{E}$ at altitude $200-300 \mathrm{~m}$ above sea level; mean temperature of $25-29^{\circ} \mathrm{C}$ and the average annual rainfall of about $1250 \mathrm{~mm}$. The samples were collected at the peak of dry season, between the months of February and March. About $350 \mathrm{~g}$ of each sample were collected, ages of the plants were not known but relatively matured leaves were collected. The forages were air dried and later oven dried at $65^{\circ} \mathrm{C}$ and weighed to determine the dry matter composition.

\subsection{Qualitative Determination of the Antinutritional Factors in Forages}

Qualitative analysis was carried out as described by [9]. Two ( $2 \mathrm{~g})$ each of ground seeds were weighed into extraction bottles in duplicate for extraction. $30 \mathrm{~mL}$ of petroleum ether and methanol-water $9: 1(\mathrm{v} / \mathrm{v})$ mixture were added to each extraction bottle. 90 minutes agitation of mixture was done on a mechanical orbital shaker at 250 revolutions per minute. The agitated mixture was filtered and separated using separating funnel. The residue was rinsed with a mixture. Two distinct layers formed in the filtrate were separated into a $50 \mathrm{~mL}$ volumetric flask each. Extractant was used to make up to $50 \mathrm{~mL}$ mark with each of fractions and labelled as the Methanol/Water (MW) fraction and the petroleum ether (PE) fraction.

Qualitative Determination of saponin, phenol and alkaloid from MW fraction while steroid was from PE fraction extract.

\subsubsection{Qualitative Determination of Saponin in Forages}

Determination of saponin form MW fraction by dispensing $1.67 \mathrm{~mL} \mathrm{MW}$ fraction into $9 \mathrm{~mL}$ distilled water and carefully filtered. Using a micro shaker $1 \mathrm{~mL}$ of the filtrate in a test tube agitated for 30 seconds and allowed to stand for 15 minutes. Height of foam in the tube measured reflects saponin content could be qualitatively evaluated: negligible (5mm or less), low $(5-9 \mathrm{~mm})$, medium $(10-14 \mathrm{~mm})$ and high ( $15 \mathrm{~mm}$ or more).

\subsubsection{Qualitative Determination of Phenol in Forages}

Determined of phenol from MW fraction extract by dispensing $1 \mathrm{~mL} \mathrm{MW}$ fraction into five recipients and $\mathrm{FeCl}_{3}$ $(5 \mathrm{~g} / 100 \mathrm{~mL}: \mathrm{W} / \mathrm{V})$ was added at different levels $(0.2,0.4$,
0.6, 0.8 and $1 \mathrm{~mL}$ ). High coloured were formed between phenol and ferric ion, resulted in a blue-violet coloured solution. Phenols or tannins were scored as follows (no colour change), water soluble tannins or phenol (dark blue) and flavonoids or condensed tannins (dark green).

\subsubsection{Qualitative Determination of Alkaloid in Forages}

Alkaloid was determined (Dragendorff): $1.7 \mathrm{~g}$ basic bismuth nitrate was dissolved in a mixture of $20 \mathrm{~mL}$ acetic acid and $80 \mathrm{~mL}$ water (solution a), $20 \mathrm{~g}$ of potassium iodide in $60 \mathrm{~mL}$ water (solution $\mathrm{b}$ ); $\mathrm{a}$ and $\mathrm{b}$ were mixed $1: 1(\mathrm{v} / \mathrm{v})$ which is called stock solution, $1 \mathrm{~mL}$ of the stock solution was mixed with $2 \mathrm{~mL}$ acetic acid and $10 \mathrm{~mL}$ water (Dragendorff reagent). 4 drops of ammonium hydroxide $\left(\mathrm{NH}_{4} \mathrm{OH}\right)$ were added to $3 \mathrm{~mL}$ of the $\mathrm{MW}$ fraction. In order to concentrate the compound of interest, the sample was reduced by evaporation under nitrogen. 3 drops of acetic acid and one drop of distilled water were again added and the solution was also evaporated the same way. The final residue was dropped on the filter paper and few drops of Dragendorff reagent was covered with the residue on filter paper. A colour change to red or pink indicates the presence of alkaloids.

\subsubsection{Qualitative Determination of Steroid in Forages}

Determined of steroid from PE fraction $(10 \mathrm{~mL})$ which was evaporated under nitrogen, after which $0.5 \mathrm{~mL}$ chloroform, $0.25 \mathrm{~mL}$ acetic anhydride and $0.125 \mathrm{~mL}$ concentrated $\mathrm{H}_{2} \mathrm{SO}_{4}$ were added. Using a mechanical shaker mixture was shaken for 30 seconds. Changes in colour indicated the presence of steroid as follows: steroids (blue or green), triterpenoids (red, pink or purple) or saturated steroids or triterpenoids (light yellow).

Qualitative determinations of some antinutritional factors were also done in line with [10]; [11] and [12], with some modifications. The aqueous extract of each sample was prepared by soaking $3 \mathrm{~g}$ of dried powdered leave samples in $15 \mathrm{~mL}$ of distilled water for $12 \mathrm{~h}$ and filtered. The aqueous extracts were filtered using Whatman filter paper No 42 (125 $\mathrm{mm})$. The filtrate was washed down and made up to $30 \mathrm{~mL}$.

\subsubsection{Qualitative Determination of Triterpeniods in Forages}

Triterpenoids was further determined through (Salkowski test): Five $\mathrm{mL}$ of each extract was mixed in $2 \mathrm{~mL}$ of chloroform, and concentrated $\mathrm{H}_{2} \mathrm{SO}_{4}(3 \mathrm{~mL})$ was carefully added to form a layer. A reddish brown colouration of the inter face was formed to show positive results for the presence of triterpenoids.

\subsubsection{Qualitative Determination of Phlobatannins in Forages}

Red precipitate deposition when an aqueous extract of each plant ground leaf sample was boiled with $1 \%$ aqueous hydrochloric acid was taken as evidence for the presence of phlobatannins.

\subsubsection{Qualitative Determination of Flavonoids in Forages}

Flavonoid presence was determined by addition of $5 \mathrm{~mL}$ of dilute ammonia solution to a portion of the aqueous filtrate of 
each plant extract followed by addition of concentrated $\mathrm{H}_{2} \mathrm{SO}_{4}$. A yellow colouration observed in each extract indicated the presence of flavonoids. The yellow colouration disappeared on standing. Few drops of $1 \%$ aluminium solution were added to a portion of each filtrate. A yellow colouration was observed indicating the presence of flavonoids.

\subsubsection{Qualitative Determination of Cardiac Glycosides in Forages}

Cardiac glycosides (Keller-Killani test): Five $\mathrm{mL}$ of each aqueous extracts was treated with $2 \mathrm{~mL}$ of glacial acetic acid containing one drop of ferric chloride solution. This was underlayed with $1 \mathrm{~mL}$ of concentrated sulphuric acid. A brown ring of the interface indicated a deoxysugar characteristic of cardenolides. A violet ring may appear below the brown ring, while in the acetic acid layer, a greenish ring may form just gradually throughout thin layer.

\subsection{Quantitative Determination of the Antinutritional Factors in Forages}

\subsubsection{Determination of Total Phenols by Spectrophotometric Method}

Preparation of fat free sample: $2 \mathrm{~g}$ of each ground leaf sample was defatted with $100 \mathrm{~mL}$ of diethyl ether using a soxhlet apparatus for $2 \mathrm{~h}$.The fat free sample was boiled with $50 \mathrm{~mL}$ of ether for the extraction of the phenolic component for $15 \mathrm{~min} .5 \mathrm{~mL}$ of the extract was pipette into a $50 \mathrm{~mL}$ flask, then $10 \mathrm{~mL}$ of distilled water was added. $2 \mathrm{~mL}$ of ammonium hydroxide solution and $5 \mathrm{~mL}$ of concentrated amylalcohol were also added. The samples were made up to mark and left to react for 30min for colour development. This was measured at $505 \mathrm{~nm}$. Phenol content was calculated.

$$
\% \text { PHENOLS }=\frac{\text { absorbance of sample } \times \text { average gradient factor } \times \text { Dilution factor } \times 100}{\text { Wt. of Sample } \times 10,000 \times 1}
$$

\subsubsection{Tannin Determination}

The [13] method was used with modification: $500 \mathrm{mg}$ of the sample was weighed into a $50 \mathrm{~mL}$ plastic bottle. $50 \mathrm{~mL}$ of distilled water was added and shaken for $1 \mathrm{~h}$ in a mechanical orbital shaker. This was filtered into a $50 \mathrm{~mL}$ volumetric flask and made up to the mark. Then $5 \mathrm{~mL}$ of the filtered was pipette into a test tube and mixed with $0.2 \mathrm{~mL}$ of $0.1 \mathrm{M} \mathrm{FeCl}_{3}$ in $0 . \mathrm{I} \mathrm{N} \mathrm{HCl}$ and $0.008 \mathrm{M}$ potassium ferrocyanide. The absorbance was measured at $720 \mathrm{~nm}$ within $10 \mathrm{~min}$. A blank sample was prepared and read at the same wavelength. A standard was prepared using 0-5 $\mu \mathrm{g} / \mathrm{mL}$ tannin acid and measured. Tannin content was calculated.

$$
\% \text { TANNIN }=\frac{\text { absorbance of sample } \times \text { average gradient factor } \times \text { Dilution factor } \times 100}{\text { Wt. of Sample } \times 10,000 \times 1}
$$

\subsubsection{Flavonoid Determination}

The method of [14] was used: $10 \mathrm{~g}$ of the leaf sample was extracted twice with $100 \mathrm{~mL}$ of $80 \%$ aqueous methanol at room temperature. The whole solution was filtered through whatman filter paper No $42(125 \mathrm{~mm})$. The filtrate was later transferred into a crucible and evaporated into dryness over a water bath at $80^{\circ} \mathrm{C}$ and weighed to a constant weight. Flavonoid content was calculated.

$$
\% \text { Flavonoid }=\frac{\text { Wt.of dried extract } \times 100}{\text { Wt. of sample } \times 1}
$$

\subsubsection{Saponin Determination and Extraction}

The method used was that of [15]. The samples were ground and $20 \mathrm{~g}$ of each were put into a $500 \mathrm{~cm}^{3}$ conical flask and $100 \mathrm{~mL}$ of $20 \%$ aqueous ethanol were added. The samples were heated over a hot water bath for $4 \mathrm{~h}$ with continuous stirring at about $55^{\circ} \mathrm{C}$. The mixture was filtered and the residue re-extracted with another $200 \mathrm{~mL} 20 \%$ ethanol. The combined aqueous ethanol extracts were reduced to $40 \mathrm{~mL}$ over water bath at about $90^{\circ} \mathrm{C}$. The concentrate was transferred into a $250 \mathrm{~mL}$ separating funnel and $20 \mathrm{~mL}$ of diethyl ether was added and shaken vigorously with hand. The aqueous layer was recovered while the ether layer was discarded. The purification process with diethyl ether was repeated. $60 \mathrm{~mL}$ of $\mathrm{n}$-butanol was added. The combined n-butanol extracts were washed twice with $10 \mathrm{~mL}$ of $5 \%$ aqueous sodium chloride. The remaining solution was heated in a waterbath. After evaporation the samples were dried in the oven to a constant weight; the saponin content was calculated.

$$
\% \text { Saponin }=\frac{\text { Wt.of dried extract } \times 100}{\text { Wt. of sample } \times 1}
$$

\subsection{Statistical Analysis}

The experimental design used was Completely Randomised designed (CRD) and data collected were analysed using descriptive analysis and analysis of variance at $\mathrm{p}=0.05$. Means were separated using Duncan multiple range F-test of the [16].

\section{Results}

\subsection{Qualitative Evaluation of Antinutritional Factors in the Selected Plants Leaves}

The spot test showed that saponin and steroid were present in all the herbaceous plants, trees, shrubs and ornamental analysed, in varying levels either as steroid, triterpenoid or saturated form of either. Steroid was saturated in Amaranthus spp. Vernonia amygdalina and Helianthus tuberosus contained steroidal saponin but does not contained triterpeniod while others contained saturated 
steroid and triterpeniod. Alkaloids was absent in all while triterpeniod was absent in all except Physalis angulata and Spigelia antheimia. Flavonoid, a phenolic compound was present in Celosia argentous, Tridax procumbens, Physalis angulate, Albizia saman, Glyricidia sepium, Ocimum gratissiumum and Morinda lucida foliage. Pholobatannins were present in the leaves of Amaranthus spp, Ocimum gratissiumum and Vernonia amygdalina but absent in leaves of all trees analysed. Newbouldia laevis had analysed saturated steroid and triterpeniod. Cardiac glycoside was absent in all tree analysed except Adanzonia digitata. In the shrub and ornamentals plants, Cardiac glycoside was present in Vernonia amygdalina and Aloe vera.

Table 1. Qualitative evaluation of antinutritional factors from leaves of some selected herbaceous plants.

\begin{tabular}{|c|c|c|c|c|c|c|c|}
\hline Herbaceous plants & Saponin & Steroid & Triterpenoid & Alkaloids & Cardiac glycoside & Phlobatanins & Flavonoid \\
\hline Celosia argentous & $+\mathrm{ve}$ & Green & -ve & -ve & -ve & -ve & dark green \\
\hline Amaranthus spinosus & + ve & light yellow & -ve & -ve & -ve & $+\mathrm{ve}$ & -ve \\
\hline Amaranthus hybridus & + ve & light yellow & -ve & -ve & -ve & $+\mathrm{ve}$ & -ve \\
\hline Corchorus olitorium & $+\mathrm{ve}$ & Green & -ve & -ve & $+\mathrm{ve}$ & -ve & -ve \\
\hline Talinum triangulae & + ve & Green & -ve & -ve & $+\mathrm{ve}$ & -ve & -ve \\
\hline Physalis angulate & $+\mathrm{ve}$ & Green & reddish brown & -ve & $+\mathrm{ve}$ & -ve & dark green \\
\hline Spigelia antheimia & $+\mathrm{ve}$ & Green & reddish brown & -ve & $+\mathrm{ve}$ & -ve & -ve \\
\hline
\end{tabular}

Presence of constituent $=+$ ve, Absence of constituent $=-\mathrm{ve}$

Table 2. Qualitative evaluation of antinutritional factors from leaves of some selected trees.

\begin{tabular}{|c|c|c|c|c|c|c|c|}
\hline Trees & Saponin & Steroid & Triterpenoid & Alkaloids & Cardiac glycoside & Phlobatanins & Flavonoid \\
\hline Albizia saman & $+\mathrm{ve}$ & Green & $-\mathrm{ve}$ & -ve & -ve & -ve & dark green \\
\hline Newbouldia laevis & $+\mathrm{ve}$ & light yellow & reddish brown & -ve & -ve & -ve & -ve \\
\hline Adanzonia digitata & $+\mathrm{ve}$ & Green & -ve & -ve & + ve & -ve & -ve \\
\hline Glyricidia sepium & $+\mathrm{ve}$ & Green & -ve & -ve & -ve & -ve & dark green \\
\hline
\end{tabular}

Presence of constituent=+ve, Absence of constituent $=-\mathrm{ve}$

Table 3. Qualitative evaluation of antinutritional factors from leaves of some selected shrubs and ornamentals.

\begin{tabular}{|c|c|c|c|c|c|c|c|}
\hline Shrubs and ornamentals & Saponin & Steroid & Triterpenoid & Alkaloids & Cardiac glycoside & Phlobatanins & Flavonoid \\
\hline Ocimum gratissiumum & $+\mathrm{ve}$ & light yellow & reddish brown & -ve & -ve & $+\mathrm{ve}$ & dark green \\
\hline Vernonia amygdalina & $+\mathrm{ve}$ & Green & -ve & $-\mathrm{ve}$ & $+\mathrm{ve}$ & $+\mathrm{ve}$ & -ve \\
\hline Euphorbia unispina & $+\mathrm{ve}$ & light yellow & -ve & -ve & -ve & -ve & -ve \\
\hline Morinda lucida & $+\mathrm{ve}$ & light yellow & reddish brown & -ve & -ve & -ve & dark green \\
\hline Aloe vera & + ve & light yellow & reddish brown & -ve & $+\mathrm{ve}$ & -ve & -ve \\
\hline Helianthus tuberosus & $+\mathrm{ve}$ & Green & -ve & -ve & -ve & -ve & -ve \\
\hline
\end{tabular}

Presence of constituent=+ve, Absence of constituent $=-\mathrm{ve}$

\subsection{Quantitative Evaluation of Antinutritional Factors in the Selected Plants Leaves}

The value of phenol and tannin ranged from $0.66 \pm 0.17$ and $0.58 \pm 0.16$ to $3.18 \pm 0.86$ and $2.80 \pm 0.76 \mathrm{~g} / 100 \mathrm{gDM}$ in Corchorus olitorium and Talinum triangulae while Flavonoid ranged $3.32 \pm 0.26$ to $10.52 \pm 0.83 \mathrm{~g} / 100 \mathrm{gDM}$ in Spigelia antheimia to Physalis angulata respectively among selected herbaceous plants. Saponin was relatively high in all the foliages with a range of 12.65 to $16.54 \mathrm{~g} / 100 \mathrm{gDM}$ in Spigelia antheimia and Talinum triangulae respectively at $\mathrm{p}<0.05$.

Phenol and tannin from some selected trees ranged from $0.97 \pm 0.29$ and $0.85 \pm 0.25 \mathrm{~g} / 100 \mathrm{gDM}$ in Glyricidia sepium to $1.47 \pm 0.43$ and $1.30 \pm 0.39 \mathrm{~g} / 100 \mathrm{gDM}$ in Albizia saman respectively. Flavonoid and saponin varied significantly at $(\mathrm{p}<0.05)$ among foliages of selected trees. Saponin ranged from $6.22 \pm 0.24 \mathrm{~g} / 100 \mathrm{gDM}$ in Adanzonia digitata to $14.37 \pm 0.56 \mathrm{~g} / 100 \mathrm{gDM}$ in Glyricidia sepium.

The crude saponin, flavonoid, phenol and tannin varied significantly $(\mathrm{p}<0.05)$ amongst the shrubs and ornamentals. Vernonia amygdalina had the highest value of phenol, tannins, flavonoids and saponin of $2.98 \pm 0.89,2.62 \pm 0.78$, $8.63 \pm 0.64$ and $19.53 \pm 1.60 \mathrm{~g} / 100 \mathrm{gDM}$ respectively. The phenol and tannin contained in Ocimum gratissiumum, Euphorbia unispina, Morinda lucida, Aloe vera and Helianthus tuberosus were significantly the same. The value of flavonoid and saponin were least in Euphorbia unispina of 2.02 and $9.18 \mathrm{~g} / 100 \mathrm{gDM}$ respectively. Saponin was relatively high in shrubs and ornamental at $(\mathrm{p}<0.05)$. 
Table 4. Percentage of crude saponin, flavonoid, phenol and tannin from leaves of some selected herbaceous plant.

\begin{tabular}{lllll}
\hline Herbaceous & Phenol & Tannin & Flavonoid & Saponin \\
\hline plants & Mean \pm SD & Mean \pm SD & Mean \pm SD & Mean \pm SD \\
\hline Celosia argentous & $1.59^{\mathrm{bc}} \pm 0.43$ & $1.40^{\mathrm{bc}} \pm 0.38$ & $8.64^{\mathrm{b}} \pm 0.69$ & $15.02^{\mathrm{abc}} \pm 0.97$ \\
Amaranthus spinosus & $2.01^{\mathrm{b}} \pm 0.55$ & $1.77^{\mathrm{b}} \pm 0.48$ & $4.43^{\mathrm{d}} \pm 0.35$ & $14.09^{\mathrm{dc}} \pm 0.91$ \\
Amaranthus hybridus & $1.11^{\mathrm{cd}} \pm 0.30$ & $0.98^{\mathrm{cd}} \pm 0.27$ & $5.06^{\mathrm{d}} \pm 0.40$ & $15.14^{\mathrm{abc}} \pm 0.98$ \\
Corchorus olitorium & $0.66^{\mathrm{e}} \pm 0.17$ & $0.58^{\mathrm{e}} \pm 0.16$ & $5.32^{\mathrm{d}} \pm 0.42$ & $12.75^{\mathrm{d}} \pm 0.82$ \\
Talinum triangulae & $3.18^{\mathrm{a}} \pm 0.86$ & $2.80^{\mathrm{a}} \pm 0.76$ & $5.17^{\mathrm{d}} \pm 0.41$ & $16.54^{\mathrm{a}} \pm 1.07$ \\
Tridax procumbens & $1.38^{\mathrm{bcd}} \pm 0.37$ & $1.22^{\mathrm{bcd}} \pm 0.33$ & $6.39^{\mathrm{c}} \pm 0.51$ & $14.39^{\mathrm{bc}} \pm 0.93$ \\
Physalis angulate & $1.00^{\mathrm{cd}} \pm 0.27$ & $0.88^{\mathrm{cd}} \pm 0.24$ & $10.52^{\mathrm{a}} \pm 0.83$ & $16.03^{\mathrm{ab}} \pm 1.03$ \\
Spigelia antheimia & $0.97^{\mathrm{cd}} \pm 0.26$ & $0.86^{\mathrm{cd}} \pm 0.23$ & $3.32^{\mathrm{e}} \pm 0.26$ & $12.65^{\mathrm{d}} \pm 0.81$ \\
\hline
\end{tabular}

Values are expressed as means \pm standard deviation. Mean values within a column with the same superscript letters are not significantly difference while different superscript letters denote significant difference $(\mathrm{p}<0.5)$.

Table 5. Percentage of crude saponin, flavonoid, phenol and tannin from leaves of some selected trees.

\begin{tabular}{lllll}
\hline Trees & Phenol & Tannin & Flavonoid & Saponin \\
\hline & Mean \pm SD & Mean \pm SD & Mean \pm SD & Mean \pm SD \\
\hline Albizia saman & $1.47 \pm 0.43$ & $1.30 \pm 0.39$ & $4.03^{\mathrm{a}} \pm 0.96$ & $12.70^{\mathrm{b}} \pm 0.50$ \\
Newbouldia laevis & $1.31 \pm 0.39$ & $1.15 \pm 0.34$ & $0.89^{\mathrm{b}} \pm 0.21$ & $8.57^{\mathrm{c}} \pm 0.34$ \\
Adanzonia digitata & $1.24 \pm 0.37$ & $1.09 \pm 0.33$ & $0.91^{\mathrm{b}} \pm 0.22$ & $6.22^{\mathrm{d}} \pm 0.24$ \\
Glyricidia sepium & $0.97 \pm 0.29$ & $0.85 \pm 0.25$ & $3.34^{\mathrm{a}} \pm 0.80$ & $14.37^{\mathrm{a}} \pm 0.56$ \\
\hline
\end{tabular}

Values are expressed as means \pm standard deviation. Mean values within a column with the same superscript letters are not significantly difference while different superscript letters denote significant difference $(\mathrm{p}<0.5)$.

Table 6. Percentage of crude saponin, Flavonoid, phenol and tannin from leaves of some selected shrubs and ornamentals.

\begin{tabular}{lllll}
\hline Shrubs and Ornamental & Phenol & Tannin & Flavonoid & Saponin \\
\hline & Mean \pm SD & Mean \pm SD & Mean \pm SD & Mean \pm SD \\
\hline Ocimum gratissiumum & $0.61^{\mathrm{b}} \pm 0.18$ & $0.54^{\mathrm{b}} \pm 0.16$ & $3.93^{\mathrm{c}} \pm 0.29$ & $10.64^{\mathrm{c}} \pm 0.87$ \\
Vernonia amygdalina & $2.98^{\mathrm{a}} \pm 0.89$ & $2.62^{\mathrm{a}} \pm 0.78$ & $8.63^{\mathrm{a}} \pm 0.64$ & $19.53^{\mathrm{a}} \pm 1.60$ \\
Euphorbia unispina & $0.93^{\mathrm{b}} \pm 0.28$ & $0.82^{\mathrm{b}} \pm 0.25$ & $2.02^{\mathrm{e}} \pm 0.15$ & $9.18^{\mathrm{c}} \pm 0.75$ \\
Morinda lucida & $0.60^{\mathrm{b}} \pm 0.18$ & $0.53^{\mathrm{b}} \pm 0.16$ & $8.21^{\mathrm{a}} \pm 0.61$ & $15.42^{\mathrm{b}} \pm 1.27$ \\
Aloe vera & $1.01^{\mathrm{b}} \pm 0.30$ & $0.89^{\mathrm{b}} \pm 0.27$ & $2.99^{\mathrm{d}} \pm 0.22$ & $19.34^{\mathrm{a}} \pm 1.59$ \\
Helianthus tuberosus & $0.99^{\mathrm{b}} \pm 30$ & $0.87^{\mathrm{b}} \pm 0.26$ & $4.75^{\mathrm{b}} \pm 0.26$ & $17.65^{\mathrm{ab}} \pm 1.45$ \\
\hline
\end{tabular}

Values are expressed as means \pm standard deviation. Mean values within a column with the same superscript letters are not significantly difference while different superscript letters denote significant difference $(\mathrm{p}<0.5)$.

\section{Discussion}

The secondary metabolites were widely distributed in the leaves of herbaceous plants, trees, shrubs and ornamentals. Saponin was present in all at varying levels as either steroid or triterpenoid; most of the leaves contained steroidal saponin is common in plants used as herbs for their health-promoting properties [17]. The (steroid) saponin present in plants was at different quantities, depending on the nature of the plant [18]. This is in consonance with [19] who also reported that Steroids (saponin) and phlobatannins were found to be present in Spigelia anthelmia studied. Steroidal compounds are known to be hormone precursors having structural similarity to such hormone. From phytochemical screening, [1] found that Toddalia asiatica, E. cymosia and Clerodendrum myricoides contains steroids, extracts from these plants are traditionally used to improve lactation possibly because steroids act like the hormones responsible for lactation [12]. Steroidal compounds are important in pharmacy due to their relationship with such compounds as sex hormones [3]. Therefore, leaves of herbaceous plants, trees, shrubs and ornamentals can be harnessed as source of steroidal compound which can act like hormones.

The triterpenoid saponins found in some of the foliage make good promising cleansing agents. Triterpenoid saponin produced from Quillaja saponaria, a tree native to the Andes region had its bark peeled off and extracted with water by the indigenous peoples as a shampooing agent, and by the Shamans as an overall curing agent [20]. Properties of saponin include formation of foams in aqueous solution, haemolytic activity and cholesterol binding properties and bitterness. Most of the plant studied has foaming as one of their properties which suggest them as a good cleansing agents. Saponins natural tendency to ward off microbes makes them good candidates for treating fungal and yeast infections. These compounds serve as natural antibiotics, 
which help the body to fight infections and microbial invasion [21]. Hence, saponin from leaves of herbaceous plants, trees, shrubs and ornamentals can be used as natural antibiotic.

Saponin was high in most of the leaves which makes them suitable medicinally for both human and animals. Saponins are known to cause gastroenteritis, manifesting as diarrhea and dysentery in man. It also suppresses rumen protozoa by reacting with protozoan cell membrane cholesterol, causing the cells to lyse. Therefore, dosage consumed by human and animal is such that does not exceed tolerable and beneficial level. Saponins also lower blood cholesterol thereby reducing heart disease as well as inhibit cancer cells [22]. [23] Reported that it reduces body cholesterol by reducing cholesterol absorption and increasing its excretion, thereby reducing blood pressure. The values of saponin from leaves of herbaceous plants, trees, shrubs and ornamentals determined analysed were higher than 1.7-3.9 g/100 gDM reported to be present in some medicinal plants [19]; this may be due to differences in specie, plant part, age of plant and season. [24] Reported value within this range of 11.3$12.3 \mathrm{~g} / 100 \mathrm{gDM}$ from different varieties of lablab beans.

[25] Reported the high saponin level in the leaf and the low levels in the seed, pod and whole fruits as an important factor as it determines the extent of the plant parts fermentation in the rumen. Saponin in some tropical fruits was also observed as an active compound responsible for the suppression of methanogenesis in faunated and defaunated rumen fluid [8]. Therefore, leaves of tropical plants should be incorporated into ruminant feed to reduce ruminal methanogenesis. Methane production has negative effects on the animals as it is an energy loss to the animal, when methane accumulates in the rumen, it results in bloat [25]. The incorporation of saponin from leaves of herbaceous plants, trees, shrubs and ornamentals into ruminant diets, in particular roughage-based diets, might be advantageous as it would lead to higher microbial yield and lower emission of environmental polluting gases $\left(\mathrm{CO}_{2}\right.$ and $\left.\mathrm{CH}_{4}\right)$ [26]. Therefore, incorporation of these saponin containing plants into animal feed as whole or saponin extract will improve animal performance and prevent ozone layer depletion.

Phenolic compounds help to prevent the death of crop as phenolic compounds from plant extracts act as antimicrobial agent [27]. The presence of phenols [28] indicates that such plants (Dioscorea species) could act as anti inflammatory, anti-clotting, antioxidant, immune enhancers and hormone modulators [29]. Phenolics compounds, such as anthraquinones have been used as purgatives [12]. Anthraquinones are the main constituents in Clutia abyssinica roots and leaves and the extracts are traditionally used to treat stomachache and constipation. The use of plant to treat toothache has also been explained as an effect due to the antiseptic action of the phenolic compounds and the neuromuscular effects of the iridoids [1]. Therefore, foliage analysed in this study contained phenol which makes them potential antimicrobial, anti-inflammatory, anti-clotting, antioxidant, antiseptic, immune enhancers, hormone modulators and can be used to prevent and treat stomachache and constipation

Tannins are water soluble phenolic compounds with a molecular weight greater than $500 \mathrm{D}$ and with the ability to precipitate proteins from aqueous solution. They occur in almost all vascular plants. Hydrolysable tannins and condensed tannins (proanthocyanidins) are two different groups of these compounds. Generally, tree and shrub leaves contain both types of tannins. The two types differ in their nutritional and toxic effects. The condensed tannins have a more profound digestibility-reducing effect than hydrolysable tannins, whereas the latter may cause varied toxic manifestations due to hydrolysis in rumen.

In ruminants, dietary condensed tannins $(2-3 \%)$ have been shown to impart beneficial effects because they reduce the wasteful protein degradation in the rumen by the formation of a protein-tannin complex [30]. The tannin content of leaves of herbaceous plants, trees, shrubs and ornamentals was within the beneficial range with the highest value of 2.80 $\mathrm{g} / 100 \mathrm{gDM}$ in Talinum trianglae. Free condensed tannins would probably be available to form a complex with digestive enzymes such as pepsin and also with the protein of gut wall. The complex appears to dissociate post-ruminal at a low $\mathrm{pH}$ where, presumably, the protein becomes available for digestion. Also, tannins are implicated in the control of intestinal worms, and while they may reduce the digestion of nitrogen in the feed, controlled feeding of certain fodder rich in tannins particularly some tree species can have a beneficial effect [31], as well as leaves of herbaceous plants, trees, shrubs and ornamentals there by enhancing by-pass protein. Also, Tannin and saponin presence in appreciable amount in feed lead to increase intake of undegradable protein and reduction in blood cholesterol respectively [32]. Hence, foliage analysed in this study has the potential to enhance bypass protein and reduce blood cholesterol when included in ruminant feed.

Tridax procumbens among all leaves of herbaceous plants, trees, shrubs and ornamentals is widely employed as livestock and poultry feed [33], this may be due to the moderate quantity of antinutritional factors. Tannins are most effective against the degrading bacteria. [34] Reported that the total bacteria in the rumen of goats decreased significantly when the animals were fed tannins-rich plant (Acacia nilotica) and decrease in the numbers was directly proportional to the level of this feed in the diet. [35] Reported a reduced population of Ruminococcus spp and Fibrobacter spp. While fungi, protozoa and proteolytic bacteria were less affected when fed tannin rich feed. Therefore, foliage of herbaceous plants, trees, shrubs and ornamentals with high tannin contents from this study has the potential to serve as selective defaunating agents.

Alkaliods was absent in all the leaves in this study, this may be attributed to maturity of the forages. [36] Reported that total and toxic alkaloids concentration generally declines with maturity. Although, alkaloid causes central nervous system paralysis, many of these alkaloids are of great medicinal value, when properly used. According to [37], 0.2g 
of coniine, an alkaloid found in the seeds of hemlock, is fatal to an adult human, others, such as nicotine and cocaine are dangerous addictive drugs. Alkaloids extract produce long lasting hypertension and contraction of the smooth muscles of the intestine both in vivo and in vitro when administered to animals [38]. Thus, alkaloids are used in preparing poison bit for fishing, hunting and insecticides. Alkaloids and tannins produce insoluble alkaloid tannates in herbivores gut inhibiting reactions between tannins and proteins [39]; [9]. Foliage used in this study contained tannin and does not contain alkaloids, probably because of stage of maturity; this makes good source of by-pass protein as alkaloid tannates complex cannot be formed.

Flavonoids are widely distributed group of polyphenolic compounds that have been reported to act as antioxidants in various biological systems. Flavonoids function as antioxidant, anti-inflammation, free radicals, and aggregate platelets; it also prevents allergies, ulcers, hepatoxins, virus and tumors [40]; [29]. Therefore, leaves of herbaceous plants, trees, shrubs and ornamentals which contained flavonoids are potential antioxidants. These leaves can reduce suppress or inhibit cancer cells by interfering with the enzymes that produce estrogen [28]; [29].

[1] Reported tritepenoids which include: cardiac glycosides, sterols, saponins and tritepenes containing plants have the potential of solving the problem of multi-drug resistance e.g. cancer cells, helminthic, microbial infections etc. The presence of these secondary compounds, therefore, validates the use of the plants as herbal drugs in Nigeria.

\section{Conclusion}

Tropical plants such as Ocimum gratissiumum, Albizia saman, Glyricidia sepium, Talinum triangulae, Amaranthus, Helianthus tuberosus, Aloe Vera, Vernonia amygdalina etc contain appreciable antinutritional factors which can be circumvent from negative effect to great resources in human and animal medicine to treat aliments as well as feed additive for rumen manipulation to increase feed utilization, encourage bye-pass protein, prevent energy loss inform of methane by ruminants as well as conserving the environment.

\section{Acknowledgement}

Mr O. O. Afolabi of the Institute of Agricultural Research and Training (IAR\&T) Moor Plantation Ibadan Nigeria for his contribution in the successful completion of the laboratory work.

\section{References}

[1] Jeruto Pascaline, Mutai Charles, Catherine Lukhoba and Ouma George (2011). Phytochemical constituents of some medicinal plants used by the Nandis of South Nandi district, Kenya Journal of Animal \& Plant Sciences, Vol. 9(3): 12011210 .
[2] Okwu, D. E. (1999). Flavouring properties of spices on cassava Fufu. Afr. J. Roots Tuber Crops 3(2): 19-21.

[3] Okwu, D. E. (2001). Evaluation of the chemical composition of indigenous spices and flavouring Agents. Global J. Pure Appl. Sci. 7(3): 455-459.

[4] Scalbert, A. (1991). Antimicrobial properties of tannins. Phytochemistry 30:3875.

[5] Bravo, L. (1998). Polyphenols: chemistry, dietary sources, metabolism, and nutritional significance. Nutr Rev 56:317 33 .

[6] Ames, B. N., Profet, M., and Gold, L. S. (1990). Dietary pesticides (99.99\% all natural).Proc Natl Acad Sci USA $87: 77781$.

[7] Kenneth-Obosi, O. and Babayemi, O. J. (2013). Enteric methane reduction of crude saponin extract of eight herbaceous plants in Nigeria. Proceeding of Animal Science Association of Nigeria1 8:419-422.

[8] Hess, H. D., Kreuzer, M., Diaz, T. E., Lascano, C. E., Carnulla, J. E., Soliva C. R. and Machmullar, A. (2003). Saponin rich tropical fruits affect fermentation and methanogenesis in faunated and defaunatedrumen fluid. Anim. Feed Sci. Technol., 109: 79-84.

[9] Babayemi, O. J., Demeyer, D. and Fievez, V. (2004a). Nutritive value and qualitative assessment of secondary compounds in seeds of eight tropical browse, shrub and pulse legumes. Comm. Appl. Biol. Sci. 69 (1): 103-110.

[10] Sofowara, A. (1993). Medicinal plants and Traditional medicine in Africa. Spectrum Books Ltd, Ibadan, Nigeria. p. 289.

[11] Trease, G. E. and Evans, W. C. (1989). Pharmacognsy.11th edn.BrailliarTiridel Can. Macmillian publishers.

[12] Harborne, J. B. (1973). Phytochemical methods, London. Chapman and Hall, Ltd. pp. 49-188.

[13] Van-Burden, T. P. and Robinson, W. C. (1981). Formation of complexes between protein and Tannin acid. J. Agric. Food Chem. 1: 77.

[14] Boham, B. A. and Kocipai, A. C. (1994). Flavonoids and condensed tannins from leaves of Hawaiian vacciniumvaticulatumand V. calycinium. Pacific Sci. 48: 458-463.

[15] Obadoni, B. O. and Ochuko, P. O. (2001). Phytochemical studies and comparative efficacy of the crude extracts of some Homostatic plants in Edo and Delta States of Nigeria. Global J. Pure Appl. Sci. 8b:203-208.

[16] SAS (1999). Statistical Analysis System, Users Guide, SAS / STAT Version 6th Edition, SAS Institute, Inc Cary, NC, USA. Pp 346 - 350.

[17] Fenwick, G. R., Price, K. R., Tsukamoto, C. and Okubo, K. (1991). Saponins. In Saponins in Toxic Substances in Crop Plants, [FJP Fish Physiology and Biochemistry 24, $343-350$.

[18] Babayemi, O. J., Demeyer, D. and Fievez, V. (2004b). In vitro fermentation of tropical browse seeds in relation to their content of secondary metabolites. J. Anim. Feed Sci. 13(1): 31 - 34.

[19] Edeoga, H. O., Okwu, D. E. and Mbaebie, B. O. (2005). Phytochemical constituents of some Nigerian medicinal plants.African Journal of Biotechnology vol.4 (7), pp 685-688. 
[20] Francis, G., Kerem, Z., Harinder, P., Makkar, S. and Becker, K. (2002). The biological action of saponins in animal systems: a review. British Journal of Nutrition 88, $587-605$.

[21] Sodipo, O. A., Akiniyi, J. A. and Ogunbanosu (2000). Studies on certain characteristics of extracts of bark of Pansinystaliamacruceras (K. Schem) Piere. Exbeile. Global J. Pure Appl. Sci. 6: 83-87.

[22] Ryam, M. K. and Shattuck, A. D. (1994) Treating aids with Chinese Medicine North SIDE HIV Treatment Centre Chicago U.S.A. Pacific View Press Berkeley USA., pp. 16-364.

[23] Oakenfull, D. and Sidhu, G. (1990). Saponins - A useful treatment for hyperchlesterolamia: European Journal of Clinical Nutrition 44: 79-88

[24] Soetan, K. O, and Fafunso, M. A. (2010). Anti-nutritional factors of three varieties of lablab beans (lablab purpureus) Proc. 35th Conf., Nig. Soc. for Anim. Prod. 502.

[25] Babayemi, O. J. (2006). Antinutrtional Factors, Nutritive Value and in vitro Gas Production of Foliage and Fruit of Enterolobiumcyclocarpum. World Journal of Zoology 1 (2): 113-117.

[26] Makkar, H. P. S., Sen, S., Blummel, M. and Becker, K., (1998). Effects of fractions containing saponins from Yucca schedigera, Quillaja saponaria, and Acacia auriculoformison rumen.J. Agric. Food Chem. 46, 4324 - 4328.

[27] Ofokansi, K. C., Esimone, C. O. and Anele, C. K. (2005) Evaluation of the in vitro combined anti bacterial effects of the leaf extracts of Bryophyllum pinnatum (Farm Crassulaceae) and Ocimum gratissimum (FarmLabiate) Plant Prod. Res. J. 9: 23-27.

[28] Farquer, J. N. (1996). Plant sterols. Their biological effects in humans.Handbook of lipids in human nutrition. BOCA Raton FL CRC Press, pp. 101-105.

[29] Okwu, D. E. and Omodamiro, O. D. (2005). Effects of hexane extract and phytochemical content of Xylopiaaethiopia and Ocimum gratissimum on the uterus of guinea pig. Biol. Res. 3 (In Press).
[30] Barry, T. N. (1987). Secondary compounds of forages. In: Nutrition of herbivores. Hacker, J. B. and Ternouth, J. H. (eds.) A. P. Sydney pp. 91120.

[31] Fenwick, G. R., Curl, C. L., Griffiths, N. M., Heaney, R. K. and Price, K. R. (1990). Bitter principles in food plants. In: Rouseff RL, ed. Bitterness in foods and beverages; developments in food science 25. Amsterdam: Elsevier, 205 50 .

[32] Rosenthal, G. A. and Janzen, D. H. (1979): Herbivores: Their interaction with secondary plant metabolites Academic press Pg. 4, 25.

[33] Egunjobi, J. K. (1969). Some common weeds of West Africa. Bull. Res. Div. Ministry of Agric. Natural Resources Western State, Ibadan, Nigeria.

[34] Sotohy, S. A., Sayed, A. N. and Ahmed, M. M. (1997). Effect of tannin-rich plant (Acacia nilotica) on some nutritional and bacteriological parameters in goats. Deutsch.-Tierarztl. Wochenschr. 104, 432-435.

[35] McSweeney, C. S., Palmer, B., Krause, D. O. and Brooker, J. D., (1999) Rumen microbial ecology and physiology in sheep and goats fed a tannin containing diet. Tannins in Livestock and Human Nutrition. Proc. International Workshop, Adelaide, Australia, 31 May-2 June, pp.140-145.

[36] Pfister, J. A., Manners, G. D., Gardner, D. R., Price, K. W. and Ralphs, M. H. (1996). Influence of alkaloids legume seeds as animal feed. Trop. Agric. (Trinidad), 70: 169 - 173.

[37] Redmond, W. A. (2008). Alkaloids. Microsoft Encarta. Microsoft Corporation, Washington DC.

[38] Oliver-Bever B. (1989) Medicinal plants in Tropical West Africa Cambridge Uni. Cambridge, p. 70.

[39] Freeland, W. J. and Janzen, D. H. (1974). Strategies of herbivory in mammals: the role of plant secondary compounds. Am. Nat., 108:269-289.

[40] Barakat, M. Z., Shahab, S. K., Darwin, N. and Zahemy, E. I. (1993). Determination of ascorbic acid from plants. Anal.Biochem. 53: 225-245. 